\title{
Granitoids and dykes of the Pine Island Bay region, West Antarctica
}

\author{
ANDREA KIPF ${ }^{1}$, NICHOLAS MORTIMER ${ }^{2}$, REINHARD WERNER ${ }^{1 *}, \mathrm{KARSTEN} \mathrm{GOHL}^{3}$, \\ PAUL VAN DEN BOGAARD ${ }^{1}$, FOLKMAR HAUFF ${ }^{1}$ and KAJ HOERNLE ${ }^{1}$ \\ ${ }^{1}$ Helmholtz-Zentrum für Ozeanforschung Kiel (GEOMAR), Wischhofstr. 1-3, D-24148 Kiel, Germany \\ ${ }^{2}$ GNS Science, Private Bag 1930, Dunedin, New Zealand \\ ${ }^{3}$ Alfred Wegener Institut für Polar- und Meeresforschung, Postfach 120161, D-27515 Bremerhaven, Germany \\ *Corresponding author: rwerner@geomar.de
}

\begin{abstract}
We present geochronological and geochemical data for eight plutonic rocks from five locations in the Pine Island Bay area of West Antarctica, collected during RV Polarstern expedition ANT-XXIII/4. Ar-Ar laser method dating yielded closure temperatures ages of $c$. 147-98 Ma for dioritic and granitic plutonic rocks and an age range of $c$. 97-95 Ma for granitoid and trachyandesitic dykes. Major and trace element compositions indicate that all rocks have an I-type subduction-related chemistry. There are no A-type granitic rocks in our dataset, and none are yet reported from the Pine Island Bay area. Our results confirm earlier models of post 100 Ma subduction on this part of the Gondwana margin.
\end{abstract}

Received 10 October 2011, accepted 9 February 2012, first published online 14 May 2012

Key words: ${ }^{40} \mathrm{Ar} /{ }^{39} \mathrm{Ar}$ geochronology, geochemistry, Gondwana, granites, tectonics

\section{Introduction}

Coastal West Antarctica (Fig. 1) consists of three major crustal blocks, Marie Byrd Land (MBL), Thurston Island and the Antarctic Peninsula (e.g. Vaughan \& Storey 2000). The Thurston Island block is separated from the MBL block by Pine Island Bay, and from the Antarctic Peninsula block by Eltanin Bay and Ronne Entrance. Whether the deep glacial troughs of both embayments follow the block boundaries, is still unknown. Until $90-83 \mathrm{Ma}$, West Antarctica formed part of the Gondwana supercontinent along with Zealandia and Australia. The conjugate margins of West Antarctica and Zealandia are key locations for understanding processes that cause supercontinent breakup. Whereas reasonably comprehensive Cretaceous geological datasets and syntheses exist for Zealandia (e.g. Tulloch \& Kimbrough 2003, Tulloch et al. 2009), Marie Byrd Land (e.g. Weaver et al. 1992, 1994, Pankhurst et al. 1998, Storey et al. 1999, Mukasa \& Dalziel 2000) and the Antarctic Peninsula (e.g. Leat et al. 1995, Wareham et al. 1997, Vaughan \& Storey 2000), much less is known about the Thurston Island block because of more remote access and greater ice sheet coverage.

During RV Polarstern expedition ANT-XXIII/4 to the Amundsen Sea embayment in 2006, several ice-free basement outcrops were visited along the coast of easternmost MBL and on small islands in Pine Island Bay that are part of the Thurston Island block (Fig. 2). In the course of this expedition, four of these outcrops were surveyed and sampled using small boat and helicopter support. Subsequently dredge material from a fifth location was obtained. In this paper, we report results of Ar-Ar laser method radiometric dating and geochemical analyses of the recovered plutonic and dyke rocks. The data and results presented in this study contribute to the small but growing geological understanding of this part of the Antarctic margin.

\section{Geological and tectonic setting}

Geological knowledge of the Pine Island Bay area (Fig. 2) is based on early reconnaissance mapping along the coast by, for example, Craddock et al. (1964) and later geochronological and geochemical sampling by Leat et al. (1993), Pankhurst et al. $(1993,1998)$ and Mukasa \& Dalziel (2000). This work has shown that episodic I-type subduction-related plutonism and volcanism occurred from the Permian to the Early Cretaceous throughout the Pine Island Bay-Thurston Island area, and that minor older gneissic basement is also present. The West Antarctica coastline provides a very oblique cross section across the Mesozoic-Paleozoic orogenic belts of Gondwana. Pankhurst et al. (1998) divided MBL into two geological provinces, Ross Province in the west and Amundsen Province in the east, with the boundary at $c .140^{\circ} \mathrm{W}$ (Fig. 1). The Amundsen Province (which includes Pine Island Bay), is a Permian to Mesozoic Gondwana-margin batholithic belt that is spatially continuous with the Pacific Margin Magnetic Anomaly of Maslanyj \& Storey (1990), the Antarctic Peninsula Batholith of Leat et al. (1995) and the Central Domain of Vaughan \& Storey (2000). Prior to Gondwana breakup the batholith also continued into the Median Batholith of New Zealand (Pankhurst et al. 1998). 


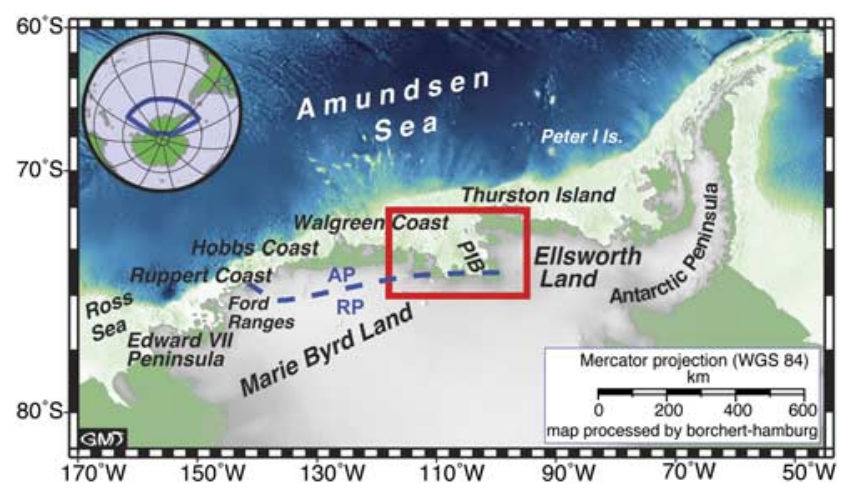

Fig. 1. Overview map of West Antarctica. The red box indicates the map area shown in Fig. 2, the dashed blue line marks the boundary between Amundsen Province (AP) and Ross Province (RP) after Pankhurst et al. (1998). Map based on ETOPO 1-minute grid (Smith \& Sandwell 1997). PIB = Pine Island Bay.

Several studies have addressed the age of cessation of subduction-related magmatism in West Antarctica. In MBL, a 124-108 Ma suite of calc-alkalic, metaluminous I-type granitoids reflects the final stage of subduction prior to its cessation beneath the Zealandia/West Antarctic Gondwana margin (e.g. Bradshaw 1989, Weaver et al. 1994). According to Weaver et al. (1994), subduction ceased at $105 \mathrm{Ma}$ in western MBL (Ruppert and Hobbs coasts). The onset of intracontinental rifting in western MBL is clearly indicated by $102-95 \mathrm{Ma}$ alkalic, metaluminous to peralkaline A-type granitoids, which make up about $75 \%$ of the exposed rocks at the Ruppert and Hobbs coasts (e.g. Weaver et al. 1994). These interpretations were supported by the western MBL U-Pb study of Mukasa \& Dalziel (2000) who reported their youngest dated subduction-related I-type pluton to be $110 \mathrm{Ma}$, A-type plutons to range from $102-98 \mathrm{Ma}$ and rift-related mafic and intermediate dykes to be $101 \pm 1 \mathrm{Ma}$. Siddoway et al. (2004) interpreted mylonitic gneisses and granites to be an indication of crustal extension in western MBL at 98-95 Ma.

In eastern MBL (Walgreen Coast to western Pine Island Bay, Fig. 1), which had Chatham Rise between it and the subducting margin, subduction-related I-type magmatism occurred at least until $94 \pm 3 \mathrm{Ma}$ (U-Pb zircon date), the implication being that, in MBL, subduction ceased earlier in the west than in the east (Mukasa \& Dalziel 2000). The change from subduction to rifting has been related to forces acting upon the plate margins by interaction of the

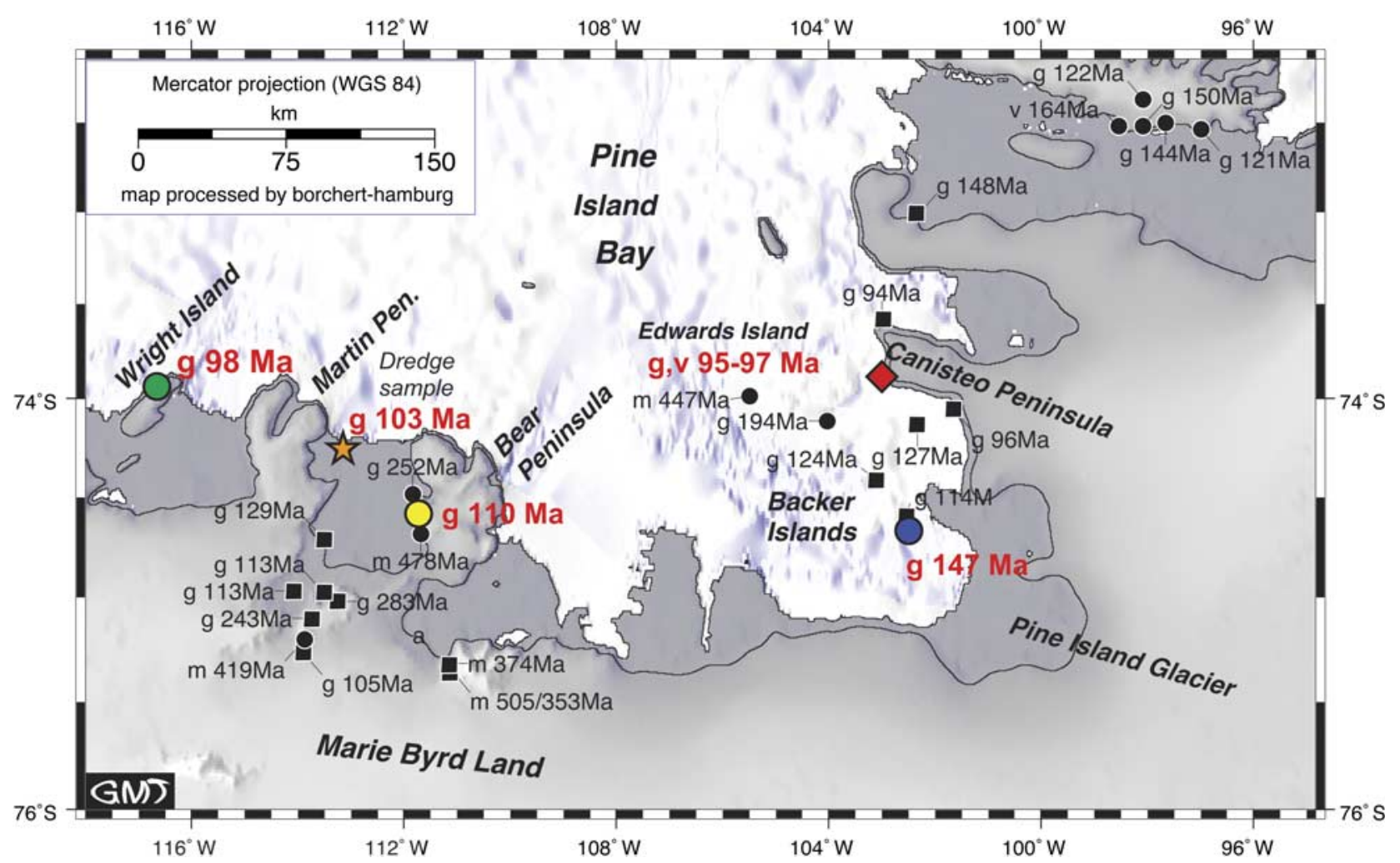

Fig. 2. Overview map of the Walgreen Coast and Pine Island Bay area. RV Polarstern expedition ANT-XXIII/4 sampling sites of the igneous basement are marked by coloured symbols (the same coloured symbols are used in subsequent figures). Bold red numbers indicate Ar-Ar ages presented in this study, small black numbers published age data from Pankhurst et al. (1993, 1998) and Mukasa \& Dalziel (2000). U-Pb ages are marked by black squares. Letters indicate rock types which have been dated ( $\mathrm{g}=$ granitoids, $\mathrm{m}=$ metamorphic rocks, $\mathrm{v}=$ volcanic rocks). Map based on ETOPO 1-minute grid (Smith \& Sandwell 1997). 
Table I. Sample locations.

\begin{tabular}{|c|c|c|c|c|c|}
\hline No. & Location name & Sample type & Latitude & Longitude & Elevation \\
\hline $277-1$ & Wright Island & granodiorite & $73^{\circ} 57.72^{\prime} \mathrm{S}$ & $116^{\circ} 52.38^{\prime} \mathrm{W}$ & $3 \mathrm{~m}$ a.s.1. \\
\hline BI-5 & Bear Peninsula & granite & $74^{\circ} 34.74 ' \mathrm{~S}$ & $111^{\circ} 53.38^{\prime} \mathrm{W}$ & $470-490 \mathrm{~m}$ a.s.1. \\
\hline PIB-1 & Backer Islands & granite & $74^{\circ} 30.66^{\prime} \mathrm{S}$ & $102^{\circ} 26.36^{\prime} \mathrm{W}$ & $6 \mathrm{~m}$ a.s.1. \\
\hline LI-1 & Edwards Island & trachyandesitic dyke & $73^{\circ} 51.17^{\prime} \mathrm{S}$ & $102^{\circ} 59.33^{\prime} \mathrm{W}$ & $10 \mathrm{~m}$ a.s.1. \\
\hline LI-2 & Edwards Island & alkali-granitic & $73^{\circ} 51.17 ' \mathrm{~S}$ & $102^{\circ} 59.33^{\prime} \mathrm{W}$ & $2 \mathrm{~m}$ a.s.1. \\
\hline DR193.1 & $\begin{array}{l}\text { c. } 20 \text { nautical miles west } \\
\text { off Bear Peninsula }\end{array}$ & granite & $74^{\circ} 09.30^{\prime} \mathrm{S}$ & $112^{\circ} 50.8^{\prime} \mathrm{W}$ & $600 \mathrm{~m}$ b.s.1. \\
\hline
\end{tabular}

palaeosubduction zone at the Zealandia/MBL margin of Gondwana with: 1) the Pacific-Phoenix spreading centre (e.g. Bradshaw 1989, Luyendyk 1995, Mukasa \& Dalziel 2000), 2) the collision of the Hikurangi Plateau with Zealandia (e.g. Bradshaw 1989, Davy et al. 2008), and/or 3) the activity of a mantle plume (e.g. Weaver et al. 1994,
Storey et al. 1999, Hoernle et al. 2010). Storey et al. (1999), for example, claimed to have identified HIMU $\mathrm{Pb}$-isotope signatures (high time-integrated $\mathrm{U} / \mathrm{Pb}$-ratios in the source region) in Late Cretaceous mafic alkaline dykes of MBL, which may indicate the involvement of a mantle plume in the final breakup.

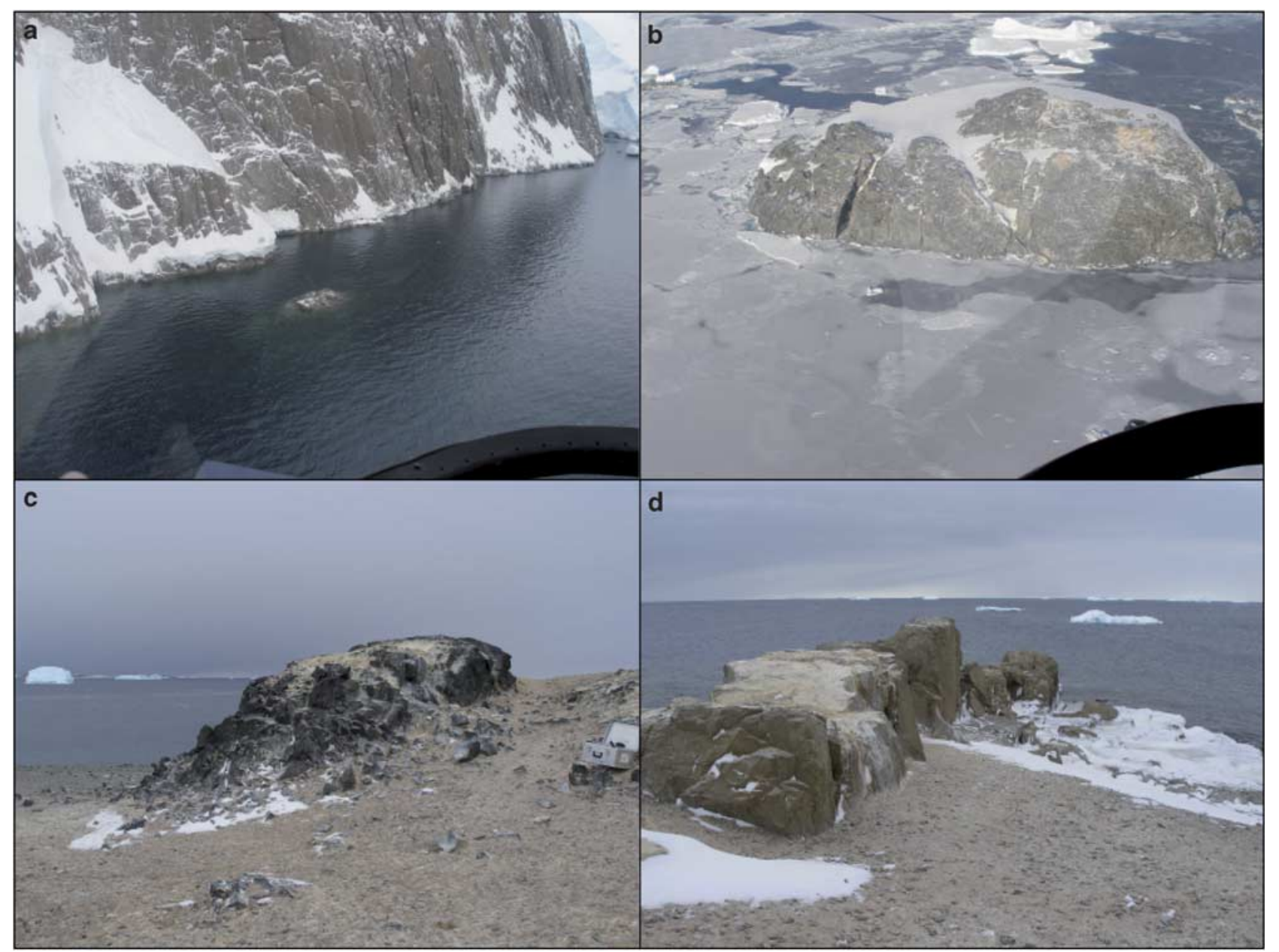

Fig. 3. Outcrops in the Walgreen Coast and Pine Island Bay area. a. Huge cliffs expose crystalline basement at the north-western coast of Wright Island. Samples PS69/277-1 and -7 were taken from the small island in front of the cliffs. b. Most islands surveyed on cruise ANTXXIII/4 in the Pine Island Bay consist mainly of granitic rocks. c. A porphyritic dyke (sample PS69/LI-1), and d. granitic rocks (samples PS69/LI-2 and -3) on Edwards Island. Note the dyke-like structure of the granitic outcrop. 
Table II. Sr-Nd-Pb isotope ratios of sample PS69/LI-1.

\begin{tabular}{|c|c|}
\hline Sample & PS69/LI-1 \\
\hline Age(My) & 97.1 \\
\hline${ }^{87} \mathrm{Sr} /{ }^{86} \mathrm{Sr}$ & 0.705455 \\
\hline $2 \mathrm{SE}(\mathrm{M})$ & 0.000005 \\
\hline $\mathrm{Rb}$ (ppm) & 56.3 \\
\hline $\mathrm{Sr}$ (ppm) & 693 \\
\hline${ }^{87} \mathrm{Rb} / 86 \mathrm{Sr}$ & 0.235 \\
\hline${ }^{87} \mathrm{Sr} /{ }^{86} \mathrm{Sr} \_\mathrm{i}$ & 0.705131 \\
\hline${ }^{143} \mathrm{Nd} /{ }^{144} \mathrm{Nd}$ & 0.512596 \\
\hline $2 \mathrm{SE}(\mathrm{M})$ & 0.000002 \\
\hline$\varepsilon N d$ & -0.81 \\
\hline $\mathrm{Sm}$ (ppm) & 5.26 \\
\hline $\mathrm{Nd}(\mathrm{ppm})$ & 28.2 \\
\hline${ }^{147} \mathrm{Sm} /{ }^{144} \mathrm{Nd}$ & 0.112 \\
\hline${ }^{143} \mathrm{Nd} /{ }^{144} \mathrm{Nd} \_\mathrm{i}$ & 0.512525 \\
\hline$\varepsilon N d \_i$ & 0.23 \\
\hline${ }^{206} \mathrm{~Pb} /{ }^{204} \mathrm{~Pb}$ & 18.8452 \\
\hline $2 \mathrm{SE}(\mathrm{M})$ & 0.0006 \\
\hline${ }^{207} \mathrm{~Pb} /{ }^{204} \mathrm{~Pb}$ & 15.6396 \\
\hline $2 \mathrm{SE}(\mathrm{M})$ & 0.0005 \\
\hline${ }^{208} \mathrm{~Pb} /{ }^{204} \mathrm{~Pb}$ & 38.6728 \\
\hline $2 \mathrm{SE}(\mathrm{M})$ & 0.0015 \\
\hline $\mathrm{Pb}(\mathrm{ppm})$ & 12.3 \\
\hline $\mathrm{U}(\mathrm{ppm})$ & 1.82 \\
\hline Th (ppm) & 8.16 \\
\hline${ }^{238} \mathrm{U} /{ }^{204} \mathrm{~Pb}$ & 9.48 \\
\hline${ }^{232} \mathrm{Th} /{ }^{204} \mathrm{~Pb}$ & 43.9 \\
\hline${ }^{206} \mathrm{~Pb} /{ }^{204} \mathrm{~Pb} \_\mathrm{i}$ & 18.70 \\
\hline${ }^{207} \mathrm{~Pb} /{ }^{204} \mathrm{~Pb} \mathrm{i}$ & 15.63 \\
\hline${ }^{208} \mathrm{~Pb} /{ }^{204} \mathrm{~Pb} \_\mathrm{i}$ & 38.46 \\
\hline
\end{tabular}

Standards measured along with the sample were normalized and gave ${ }^{87} \mathrm{Sr} /{ }^{86} \mathrm{Sr}=0.710250 \pm 10 \quad(n=10,2 \sigma$ external $)$ for NBS987 on the MAT262 and ${ }^{143} \mathrm{Nd} /{ }^{144} \mathrm{Nd}=0.511850 \pm 8(n=13,2 \sigma$ external $)$ for $\mathrm{La}$ Jolla on the TRITON. Pb double-spike corrected values for NBS981 are ${ }^{206} \mathrm{~Pb} /{ }^{204} \mathrm{~Pb}=16.9416 \pm 21, \quad{ }^{207} \mathrm{~Pb} /{ }^{204} \mathrm{~Pb}=15.4996 \pm 20 \quad$ and ${ }^{208} \mathrm{~Pb} /{ }^{204} \mathrm{~Pb}=36.7231 \pm 52(n=45,2 \sigma$ external $)$ on the MAT262 during the period 2006-08 when the data for this sample was acquired. All errors refer to the last significant digit. $2 \mathrm{SE}(\mathrm{M})=2$ sigma error of the mean, $\_\mathrm{i}=$ initial isotopic ratio using the age (Table III) and the trace element concentrations (Table IV) of the sample.

\section{Sample background}

Rock sampling was conducted on Wright Island and Bear Peninsula along the Walgreen Coast and on two islands within Pine Island Bay, an area that has been sampled by earlier expeditions (Fig. 2, Table I). Additionally, a granitic sample (DR 193.1, kindly provided by R.D. Larter, British Antarctic Survey) dredged c. 20 nautical miles west of Bear Peninsula at c. $600 \mathrm{~m}$ water depth during RRS James Clark Ross cruise JR141 has been dated for this study, but not geochemically analysed because of the small sample size.

On the north-western coast of Wright Island of the Walgreen Coast, huge cliffs expose outcrops of relatively fine-grained crystalline basement (Fig. 3a, samples PS69/ 277-1 and -7), cut by several (inaccessible) dykes. Dark biotite-rich inclusions and dykes a few centimetres wide are

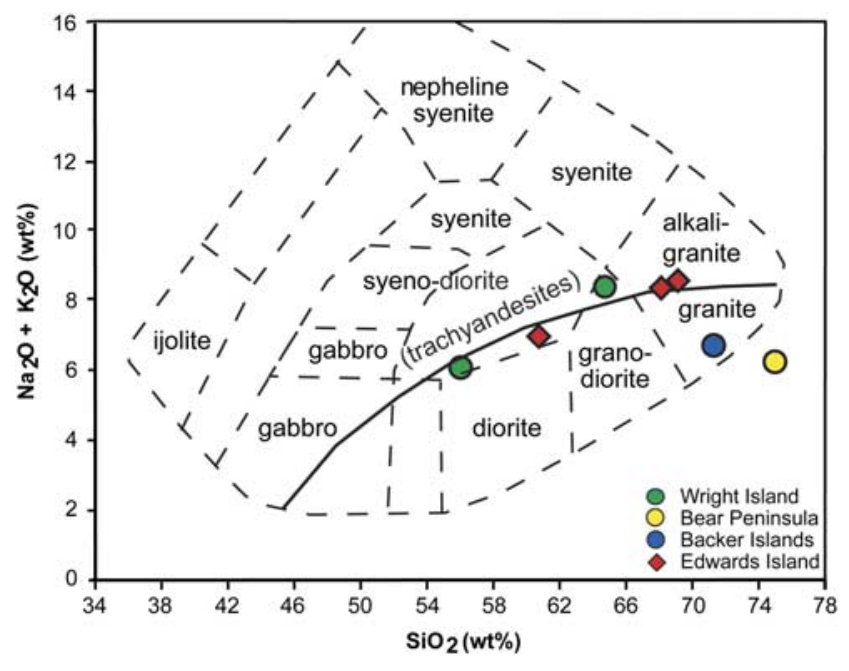

Fig. 4. Classification of the samples from Walgreen Coast and Pine Island Bay. The solid line marks the subdivision between alkalic and subalkalic rocks. All samples show evolved subalkalic or slightly alkalic compositions. The porphyritic dyke rock sampled on Edwards Island falls into the field for trachyandesites. All analyses have been normalized to a volatile free total of $100 \%$.

common at the sampling site. On Bear Peninsula, relatively homogeneous, coarse-grained granitic rocks outcrop c. $490 \mathrm{~m}$ above sea level on top of a smooth hill (sample PS69/BI-5). A weakly developed foliation in the granitic rocks, the common occurrence of dark xenoliths (most probably meta-sediment) and intercalated siliceous layers may indicate that this outcrop represents the edge (or roof) of a pluton, probably intruding the gneissic rocks reported and dated by Pankhurst et al. (1998).

In Pine Island Bay, Backer Islands (sample PS69/PIB-1) are part of a prominent SE-NW striking island chain, which extends from Ellsworth Land (Evans Knoll) beneath the ice-shelf north of the Pine Island Glacier. These islands mainly consist of granitic rocks and our sample was taken from the southern part of the island chain (Fig. 3b, cf. Mukasa \& Dalziel 2000). In contrast, an island group west of Canisteo Peninsula is marked by a succession of east-west striking dykes, up to a few meters wide. Our field observations on Edwards Island revealed black porphyritic dykes (Fig. 3c, sample PS69/LI-1) alternating with light, holocrystalline granitic rocks (samples PS69/ LI-2 and -3). The granitic rocks also show a dyke-like morphology (Fig. 3d), but it is not evident from field observations whether the trachyandesitic dykes intruded into a granitic host rock or all the rocks exposed on Edwards Island are dykes. Radiometric dating (see below) indicates, however, that formation and cooling of the granitic rocks occurred at the same time and after the emplacement of the trachyandesitic dykes. Therefore Edwards Island most probably consists of a succession of 
trachyandesitic and granitic dykes as suggested by the structure of the outcrops.

\section{Analytical methods}

Samples selected for geochemistry were first crushed, then repeatedly washed in de-ionized water and thereafter carefully handpicked under a binocular microscope. Major and trace element data were analysed at SARM (Service d'Analyse des Roches et des Mineraux) laboratories in France. Major elements were determined using an ICP-OES IRIS Advantage ERS - ThermoFisher, trace elements using an ICP-MS X7 - ThermoFisher. Standards BR, DR-N, UB-N, $A N-G$ and $G H$ were used for calibration. For a more detailed description of methods and reference materials see Carignan et al. (2001). The $\mathrm{Sr}-\mathrm{Nd}-\mathrm{Pb}$ isotopic composition of sample PS69/LI-1 was determined at the Helmholtz Centre for Ocean Research Kiel (GEOMAR) by thermal ionization mass spectrometry (TIMS) following the methods outlined in Hoernle et al. (2010). Measured and initial isotopic ratios along with standard values are shown in Table II.

${ }^{40} \mathrm{Ar} /{ }^{39} \mathrm{Ar}$ analyses were conducted on biotite and feldspar phenocrysts at the GEOMAR Geochronology Laboratory. The crystals were handpicked from crushed and sieved splits. Feldspar phenocrysts were etched in diluted hydrofluoric acid. All separates were cleaned using an ultrasonic disintegrator.

Minerals were irradiated in aluminium trays with a cadmium lining at the 5MW reactor of the HelmholtzZentrum Geesthacht, Centre of Materials and Coastal Research (GKSS). The neutron flux was monitored using Taylor Creek Rhyolite sanidine (TCR-2: $27.87 \pm 0.04 \mathrm{Ma}$, Lanphere \& Dalrymple 2000). ${ }^{40} \mathrm{Ar} /{ }^{39} \mathrm{Ar}$ laser step-heating analyses were carried out with a $20 \mathrm{~W}$ SpectraPhysics Argon-Ion laser and an MAP 216 series noble gas mass spectrometer. Argon isotope ratios were corrected for mass discrimination, background and blank values, J-value gradients, and interfering neutron reactions on $\mathrm{Ca}$ and $\mathrm{K}$.

Step-heating results are plotted in age spectra (apparent age and error vs cumulative ${ }^{39} \mathrm{Ar}$ ). Statistical plateaus are defined as more than three consecutive steps comprising $>50 \%$ of the ${ }^{39} \mathrm{Ar}$ released, with ages overlapping within $2 \sigma$ errors.

$36 \mathrm{Ar} / 39 \mathrm{Ar}$ ratios (biotite, K-feldspar) and ${ }^{36} \mathrm{Ar} /{ }^{37} \mathrm{Ar}$ ratios (plagioclase), both corrected for neutron reactions on $\mathrm{Ca}$ and normalized to $\mathrm{J}=0.01$, are monitored to assess the variable degree of alteration of the samples (Baksi 2007) and heating steps with excessively high alteration indices are excluded from plateau age calculations. Plateau ages represent the inverse-variance weighted mean of the (accepted) plateau steps ages and errors $(2 \sigma)$. Statistical robustness of plateaus and plateau ages are tested by the MSWD (mean square weighted deviates) and probability of fit (which should be $>0.05$ at $2 \sigma / 95 \%$ confidence levels) (Baksi 2007 and references therein).

\section{Results}

\section{Petrography and classification}

All sampled plutonic rocks are coarse-grained, (equi-) granular, holocrystalline, leucocratic granitoids. They range from medium-K syeno-diorites and high- $\mathrm{K}$ granodiorites on Wright Island to subalkaline (medium-K) granites on Bear Peninsula and Backer Islands (Fig. 4). Major constituents are quartz, alkali feldspar and zoned plagioclase. Other common mineral phases are hornblende, apatite, titanomagnetite, and biotite, while muscovite occurs rarely. Amphibole is restricted to the granites. The porphyritic dyke sample PS69/LI-1 from Edwards Island is a trachyandesite (microsyenodiorite) with a glomerophyric texture. Large feldspar

Table III. Results of step-heating ${ }^{40} \mathrm{Ar} /{ }^{39} \mathrm{Ar}$ analyses.

\begin{tabular}{|c|c|c|c|c|c|c|c|}
\hline Sample ID & Locality & Plateau age (Ma) & $2 \sigma$ & MSWD & Probability & $\%{ }^{39} \mathrm{Ar}$ in plateau & Dated material \\
\hline $277-1 \mathrm{bts}$ & Wright Island & 98.4 & \pm 0.3 & 0.50 & 0.89 & 58 & biotite \\
\hline $277-1 b t 2$ & & $98.3+$ & \pm 0.2 & 0.22 & 0.64 & & \\
\hline $277-7 \mathrm{bts}$ & Wright Island & 97.9 & \pm 0.4 & 0.24 & 1.00 & 82 & biotite \\
\hline LI-1fss & Edwards Island & 97.1 & \pm 0.5 & 1.08 & 0.37 & 88 & plagioclase \\
\hline LI-2fs2 & Edwards Island & 97.1 & \pm 0.7 & 1.50 & 0.12 & 92 & plagioclase \\
\hline PIB-1bt3 & Backer Island & 147.0 & \pm 0.6 & 1.30 & 0.23 & 61 & biotite \\
\hline \multirow[t]{2}{*}{ PIB-1bt4 } & Backer Island & 147.3 & \pm 0.6 & 1.18 & 0.31 & 50 & biotite \\
\hline & & $147.2 \dagger$ & \pm 0.4 & 0.46 & 0.50 & & \\
\hline PIB-1bt6 & Backer Island & 151.9 & \pm 0.4 & 1.30 & 0.26 & 63 & biotite \\
\hline BI-5bts, bt3, bt6 & Bear Peninsula & $109.8+t$ & \pm 1.3 & 0.53 & 0.59 & & biotite \\
\hline DR193.1 & $\begin{array}{l}\text { c. } 20 \mathrm{n} \text {. miles west } \\
\text { off Bear Peninsula }\end{array}$ & 103.5 & \pm 0.3 & 1.80 & 0.13 & 66 & plagioclase \\
\hline
\end{tabular}

tWeighted mean of plateau ages.

t+Weighted mean of "best step" averages. 
phenocrysts (up to $5 \mathrm{~mm}$ ) occur in a fine-grained matrix, which mainly consists of plagioclase, hornblende, and titanomagnetite. The other rocks sampled on Edwards Island are evolved, holocrystalline alkali-granitic rocks. Major mineral phases are quartz, sanidine, plagioclase and biotite. Hornblende, muscovite, nepheline, apatite, and titanomagnetite are minor components.

The samples from Wright Island and Bear Peninsula do not show any signs of alteration, whereas the granitic rocks from Backer and Edwards islands show minor alteration of feldspars to secondary calcite and chlorite. The trachyandesite from Edwards Island is slightly altered (minor calcite replacement of some phenocrysts).

\section{Ar-Ar laser method dating}

${ }^{40} \mathrm{Ar} /{ }^{39} \mathrm{Ar}$ step-heating results are summarized in Table III, age, alteration index spectra are shown in Fig. 5, and full analytical data are given in Table S1 (http://dx.doi.org/ 10.1017/S0954102012000259).

Two biotite step-heating analyses from Wright Island granodiorite sample 277-1 yield plateau ages of $98.4 \pm$ $0.3 \mathrm{Ma}$ and $98.3 \pm 0.4 \mathrm{Ma} .{ }^{36} \mathrm{Ar} /{ }^{39} \mathrm{Ar}$ alteration indices are reasonably low in the high temperature plateau sections (0.002-0.007), but up to three orders of magnitude higher in the low temperature heating steps (excluded from plateau). Plateau age results are identical within error, thus a weighted mean age of $98.3 \pm 0.2 \mathrm{Ma}(2 \sigma, \mathrm{MSWD}=0.22$, probability $=0.64)$ was calculated for sample 277-1.

Biotite step-heating of Wright Island syeno-diorite sample 277-7 yields a slightly younger plateau age of $97.9 \pm 0.4 \mathrm{Ma}$. Plateau step alteration indices indicate degassing from little-altered sites $\left({ }^{36} \mathrm{Ar} /{ }^{39} \mathrm{Ar}=0.003-0.006\right)$. Small low temperature fractions $\left(<18 \%{ }^{39} \mathrm{Ar}\right)$ yield higher alteration indices (0.01-10) and lower apparent ages due to a loss of radiogenic ${ }^{40} \mathrm{Ar}$ during alteration.

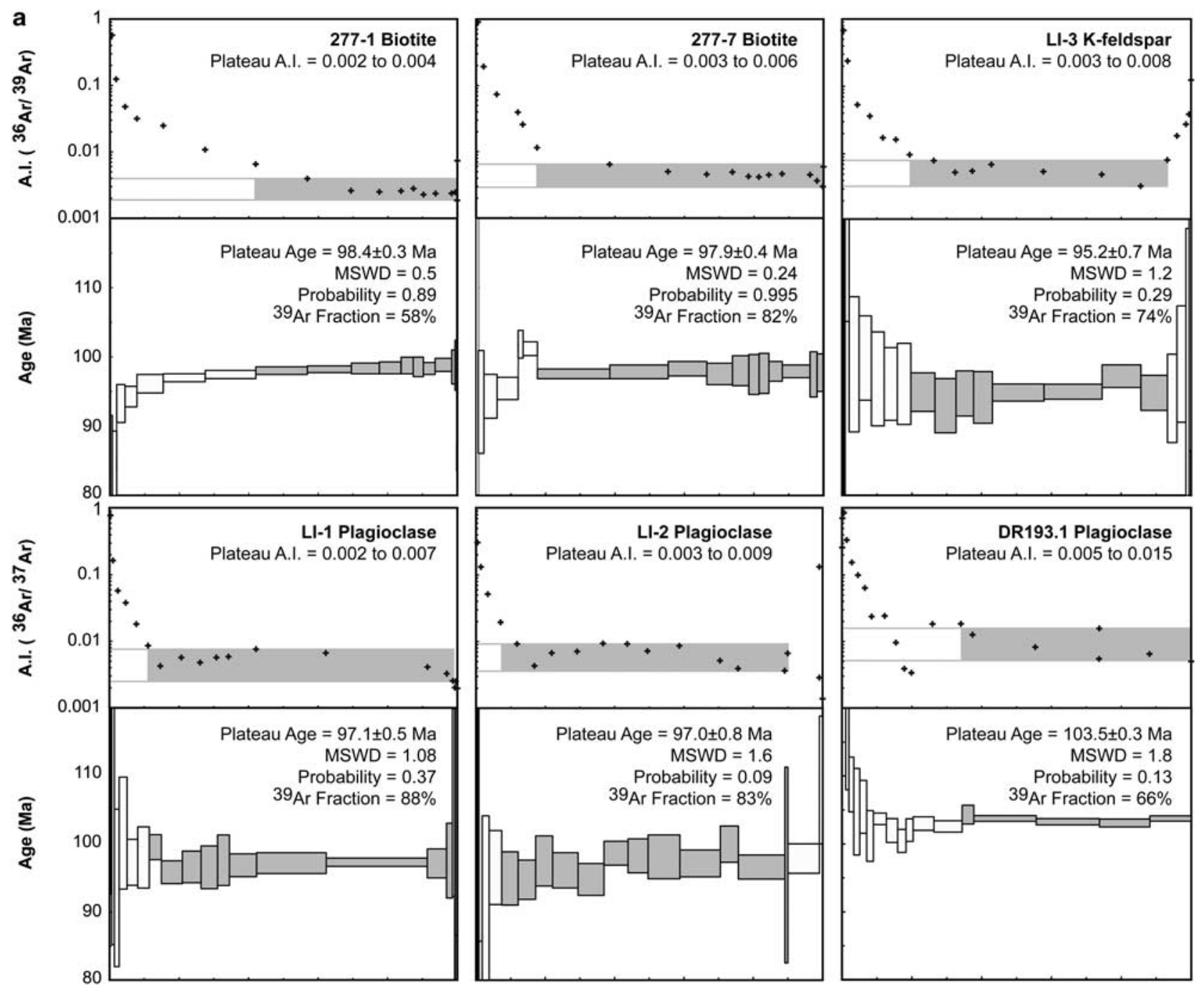

Fig. 5. Age spectra and alteration indices (A.I.) from ${ }^{40} \mathrm{Ar} /{ }^{39} \mathrm{Ar}$ laser step-heating experiments. Plateau steps and corresponding range of alteration index values are accentuated by grey shading. Error bars are $\pm 2 \sigma$. 

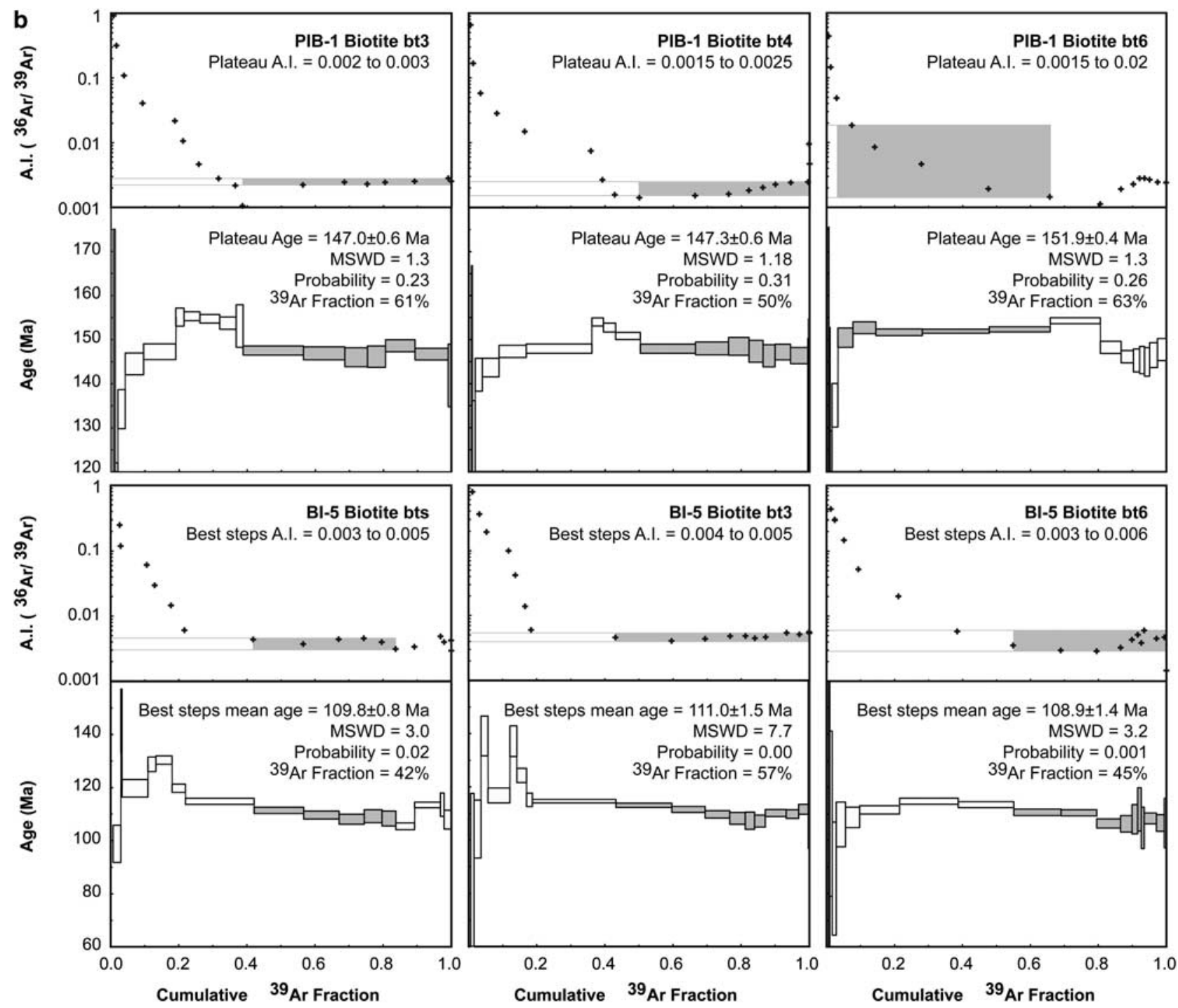

Fig. 5. Continued.

Plagioclase feldspar step-heating of Edwards Island trachyandesite dyke LI-1 yields a plateau age of $97.1 \pm 0.5 \mathrm{Ma} .{ }^{36} \mathrm{Ar} /{ }^{37} \mathrm{Ar}$ ratios are reasonably low in the high temperature plateau section (0.002-0.007), but gradually higher in the lower temperature heating steps (0.01-1.7) indicating partial alteration (steps 1-7, excluded from plateau).

Plagioclase from Edwards Island alkali-granitic rock sample LI-2 yields similar results. Alteration is low in the plateau steps $\left({ }^{36} \mathrm{Ar} /{ }^{37} \mathrm{Ar}=0.003-0.009\right)$, which yield a plateau age of $97.1 \pm 0.7 \mathrm{Ma}$. Lower temperature steps degassed more altered sites $\left({ }^{36} \mathrm{Ar} /{ }^{37} \mathrm{Ar}=0.02-2.4\right)$, and thus are rejected from the plateau. K-feldspar (anorthoclase?) step-heating of Edwards Island alkaligranite sample LI-3 yields a plateau age of $95.2 \pm 0.7 \mathrm{Ma}$ $\left({ }^{36} \mathrm{Ar} /{ }^{39} \mathrm{Ar}=0.003-0.008\right)$. Both the lowest and highest temperature steps show significantly higher alteration $\left({ }^{36} \mathrm{Ar} /{ }^{39} \mathrm{Ar}=0.01-2.2\right)$ and are rejected from the plateau age calculation.

Six step-heating analyses were carried out on biotite from Backer Islands granite sample PIB-1, three of which yielded disturbed spectra without significant $\left(>50 \%{ }^{39} \mathrm{Ar}\right)$ plateaus. Two analyses yield high temperature plateaus at $147.0 \pm 0.6 \mathrm{Ma}$ (PIB-1bt3) and 147.3 $\pm 0.6 \mathrm{Ma}$ (PIB-1bt4) with acceptable alteration indices in the plateau steps (0.002-0.003). Significant alteration in the low temperature spectrum result in apparent ages significantly lower (due to radiogenic ${ }^{40} \mathrm{Ar}$ loss?) and apparent ages significantly higher (due to recoil ${ }^{39} \mathrm{Ar}$ loss?) than the plateau ages.

Analysis PIB-1bt6 yields a low temperature plateau at $151.9 \pm 0.4 \mathrm{Ma}$, but alteration indices up to 0.02 clearly show that this plateau includes degassing from altered sites. Seven high temperature steps with low alteration indices $(0.002-0.003)$ yield apparent ages around $147 \mathrm{Ma}$ again. 
Table IV. Results of major and trace element analyses.

\begin{tabular}{|c|c|c|c|c|c|c|c|}
\hline & $\begin{array}{l}\text { PS69/ } \\
\text { 277-1-1 } \\
\text { Wright } \\
\text { Island }\end{array}$ & $\begin{array}{l}\text { PS69/ } \\
\text { 277-1-7 } \\
\text { Wright } \\
\text { Island }\end{array}$ & $\begin{array}{l}\text { PS69/ } \\
\text { BI-5 } \\
\text { Bear } \\
\text { Peninsula }\end{array}$ & $\begin{array}{l}\text { PS69/ } \\
\text { PIB-1 } \\
\text { Backer } \\
\text { Islands }\end{array}$ & $\begin{array}{l}\text { PS69/ } \\
\text { LI-1 } \\
\text { Edwards } \\
\text { Island }\end{array}$ & $\begin{array}{l}\text { PS69/ } \\
\text { LI-2 } \\
\text { Edwards } \\
\text { Island }\end{array}$ & $\begin{array}{l}\text { PS69/ } \\
\text { LI-3 } \\
\text { Edwards } \\
\text { Island }\end{array}$ \\
\hline $\mathrm{SiO}_{2}$ & 63.40 & 55.40 & 73.77 & 70.54 & 58.50 & 66.39 & 67.01 \\
\hline $\mathrm{TiO}_{2}$ & 0.52 & 1.29 & 0.27 & 0.33 & 0.80 & 0.46 & 0.41 \\
\hline $\mathrm{Al}_{2} \mathrm{O}_{3}$ & 17.23 & 18.32 & 12.83 & 14.48 & 16.67 & 15.63 & 15.36 \\
\hline $\mathrm{Fe}_{2} \mathrm{O}_{3}$ & 4.66 & 7.48 & 2.18 & 2.97 & 5.93 & 2.85 & 2.55 \\
\hline $\mathrm{MnO}$ & 0.06 & 0.13 & 0.05 & 0.05 & 0.08 & 0.08 & 0.07 \\
\hline $\mathrm{MgO}$ & 1.10 & 2.77 & 0.59 & 0.63 & 2.56 & 1.09 & 0.84 \\
\hline $\mathrm{CaO}$ & 3.14 & 7.24 & 2.10 & 2.89 & 4.89 & 2.31 & 2.02 \\
\hline $\mathrm{Na}_{2} \mathrm{O}$ & 4.77 & 4.82 & 4.05 & 4.09 & 3.95 & 4.12 & 4.12 \\
\hline $\mathrm{K}_{2} \mathrm{O}$ & 2.93 & 0.93 & 1.79 & 2.20 & 2.31 & 3.55 & 3.72 \\
\hline $\mathrm{P}_{2} \mathrm{O}_{5}$ & 0.15 & 0.42 & 0.06 & 0.11 & 0.31 & 0.17 & 0.14 \\
\hline $\mathrm{H}_{2} \mathrm{O}$ & 0.78 & 0.79 & 0.90 & 0.48 & 1.61 & 1.27 & 1.15 \\
\hline $\mathrm{CO}_{2}$ & 0.02 & 0.10 & 0.04 & 0.02 & 0.88 & 0.14 & 0.37 \\
\hline Total & 98.75 & 99.66 & 98.64 & 98.79 & 98.48 & 98.06 & 97.78 \\
\hline $\mathrm{Rb}$ & 87.9 & 84.9 & 54.7 & 87.0 & 56.3 & 128 & 136 \\
\hline $\mathrm{Ba}$ & 1018 & 995 & 527 & 853 & 749 & 877 & 941 \\
\hline Th & 7.69 & 8.10 & 5.31 & 4.52 & 8.16 & 16.0 & 17.0 \\
\hline $\mathrm{U}$ & 1.46 & 1.55 & 1.54 & 1.20 & 1.82 & 4.03 & 4.00 \\
\hline $\mathrm{Nb}$ & 7.01 & 6.73 & 4.02 & 4.76 & 6.91 & 9.40 & 9.57 \\
\hline $\mathrm{Ta}$ & 0.64 & 0.64 & 0.43 & 0.46 & 0.56 & 0.88 & 0.90 \\
\hline $\mathrm{La}$ & 35.4 & 34.3 & 15.0 & 18.4 & 27.4 & 35.0 & 35.4 \\
\hline $\mathrm{Ce}$ & 67.4 & 65.9 & 30.6 & 39.5 & 58.9 & 69.6 & 69.1 \\
\hline $\mathrm{Pb}$ & 15.3 & 15.6 & 7.2 & 18.7 & 12.3 & 16.4 & 17.2 \\
\hline $\operatorname{Pr}$ & 7.20 & 7.15 & 3.59 & 4.35 & 7.14 & 7.76 & 7.54 \\
\hline $\mathrm{Nd}$ & 25.1 & 25.1 & 14.4 & 16.2 & 28.2 & 28.0 & 27.0 \\
\hline $\mathrm{Sr}$ & 479 & 464 & 150 & 384 & 693 & 442 & 345 \\
\hline Sm & 3.91 & 3.83 & 3.20 & 3.10 & 5.26 & 4.80 & 4.54 \\
\hline $\mathrm{Hf}$ & 7.06 & 6.88 & 3.58 & 4.00 & 4.93 & 6.30 & 6.47 \\
\hline $\mathrm{Zr}$ & 299 & 289 & 127 & 163 & 197 & 258 & 267 \\
\hline $\mathrm{Eu}$ & 1.54 & 1.48 & 0.78 & 1.10 & 1.39 & 1.16 & 1.10 \\
\hline $\mathrm{Gd}$ & 2.98 & 2.79 & 3.16 & 2.30 & 3.93 & 3.56 & 3.32 \\
\hline $\mathrm{Tb}$ & 0.39 & 0.38 & 0.55 & 0.34 & 0.55 & 0.53 & 0.49 \\
\hline Dy & 2.17 & 2.15 & 3.62 & 1.92 & 3.06 & 3.00 & 2.87 \\
\hline Но & 0.42 & 0.40 & 0.79 & 0.39 & 0.58 & 0.60 & 0.57 \\
\hline Y & 12.4 & 12.4 & 23.7 & 11.6 & 16.2 & 17.9 & 17.0 \\
\hline Er & 1.20 & 1.20 & 2.41 & 1.18 & 1.58 & 1.79 & 1.71 \\
\hline $\mathrm{Tm}$ & 0.19 & 0.19 & 0.38 & 0.18 & 0.23 & 0.28 & 0.27 \\
\hline $\mathrm{Yb}$ & 1.30 & 1.31 & 2.78 & 1.25 & 1.56 & 2.05 & 2.00 \\
\hline $\mathrm{Lu}$ & 0.21 & 0.22 & 0.46 & 0.21 & 0.24 & 0.34 & 0.33 \\
\hline
\end{tabular}

This indicates that the low temperature plateau is in fact a pseudo-plateau possibly derived from a "balanced" loss of radiogenic ${ }^{40} \mathrm{Ar}$ and recoiled ${ }^{39} \mathrm{Ar}$. The biotite ${ }^{40} \mathrm{Ar} /{ }^{39} \mathrm{Ar}$ age of granite PIB-1 is determined as $147.2 \pm 0.4 \mathrm{Ma}$ $(\mathrm{MSWD}=0.46$, probability $=0.5)$ from the weighted mean of the bt 3 and bt 4 plateau age results.

Three step-heating analyses of biotite from Bear Peninsula granite sample BI-5 (bts, bt3 \& bt6) yield disturbed spectra. None of the analyses shows a significant plateau ( $\left.>50 \%{ }^{39} \mathrm{Ar}\right)$. All show effects of significant alteration, such as high ${ }^{37} \mathrm{Ar} /{ }^{39} \mathrm{Ar}$ ratios $>0.02$ indicating the presence of alteration products (chlorite, epidote) in the biotite crystals (Baksi 2007), and high ${ }^{36} \mathrm{Ar} /{ }^{39} \mathrm{Ar}$ ratios indicating substantial uptake of ${ }^{36} \mathrm{Ar}$, probable loss of radiogenic ${ }^{40} \mathrm{Ar}$ during alteration, and possible recoil
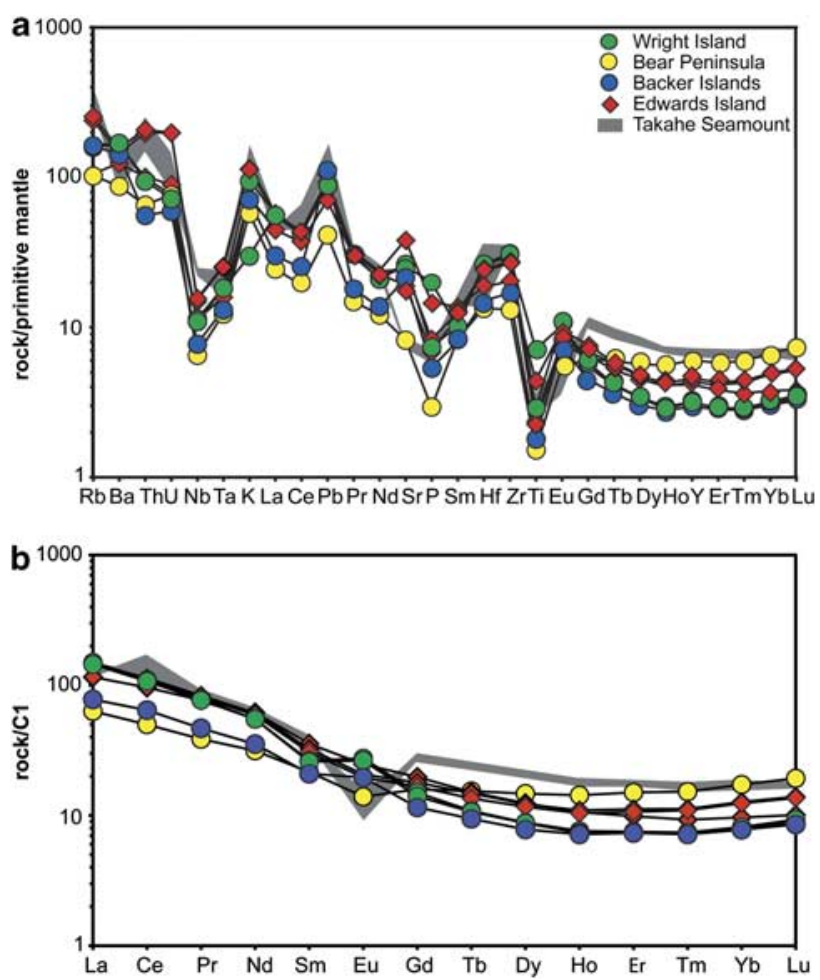

Fig. 6. Multi-element diagram normalized to primitive mantle (after Hofmann 1988) and rare earth element (REE) diagram normalized to chondrites (after McDonough \& Sun 1995) for the Walgreen Coast and Pine Island Bay rocks. The $97 \mathrm{Ma}$ granites of Takahe Seamount (Mortimer et al. 2006) are shown for reference. Note the distinct Eu anomaly for the A-type Takahe granites.

loss of ${ }^{39} \mathrm{Ar}$ during irradiation. The least altered high temperature degassing steps show acceptable alteration indices ranging from $0.003-0.006$, comprise only $42 \%$ (bts), $57 \%$ (bt3), and $45 \%$ (bt6) of the ${ }^{39} \mathrm{Ar}$ released, and yield mean ages identical within $2 \sigma$ uncertainties $/ 95 \%$ confidence levels $\quad(109.8 \pm 0.8 \mathrm{Ma}, \quad 111.0 \pm 1.5 \mathrm{Ma}$, $108.9 \pm 1.4 \mathrm{Ma})$. High MSWD $(\geq 3)$ and low probability $(P<<0.05)$ indicate excess scatter and presence of geological error. The weighted mean of these three "best steps averages" is $109.8 \pm 1.3 \mathrm{Ma}(\mathrm{MSWD}=0.53$, probability $=0.59$ ) and considered our best estimate for the biotite ${ }^{40} \mathrm{Ar} /{ }^{39} \mathrm{Ar}$ age of Bear Peninsula granite BI-5.

Plagioclase step-heating of granite sample DR193.1, dredged c. 20 nautical miles west of Bear Peninsula, yields a high temperature plateau at $103.5 \pm 0.3 \mathrm{Ma} .{ }^{36} \mathrm{Ar} /{ }^{37} \mathrm{Ar}$ ratios of the low temperature heating steps (0.01-1.0) and plateau steps (0.005-0.02) indicate partial alteration of the plagioclase crystals. The sample may have experienced minor loss of radiogenic ${ }^{40} \mathrm{Ar}$, and its age estimate may therefore be a few percent too low.

The biotite and plagioclase ${ }^{40} \mathrm{Ar} /{ }^{39} \mathrm{Ar}$ ages of the Pine Island Bay granites and diorites (277-1, 277-7, PIB-1, BI-5, DR193.1) approximate the time that passed since cooling 


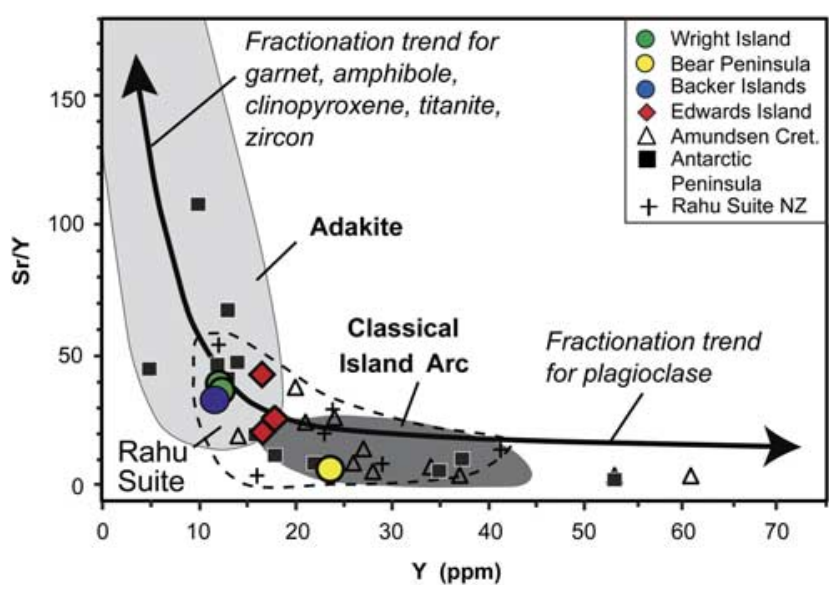

Fig. 7. $\mathrm{Y}$ vs $\mathrm{Sr} / \mathrm{Y}$ discrimination diagram after Defant \& Drummond (1990) reveals a weak adakitic composition of most Walgreen coast and Pine Island Bay samples. Only the granite sampled on Bear Peninsula falls into the fields for "classical" arc compositions. Previously published data from Cretaceous granitoids from the Amundsen suite (Pankhurst et al. 1993, 1998), the Cretaceous New Zealand Rahu Suite (Tulloch \& Kimbrough 2003) and Cretaceous sodic granites from the Antarctic Peninsula (Wareham et al. 1997) are shown for reference. Field for adakites and fractionation trends after Richards \& Kerrick (2007).

below closure temperatures (c. $300-200^{\circ} \mathrm{C}$; McDougall \& Harrison 1999, Cassata et al. 2009), and may post-date the time of emplacement and crystallization by several million years. We note, however, that there is a reasonable match between our ${ }^{40} \mathrm{Ar} /{ }^{39} \mathrm{Ar}$ ages and the published U-Pb ages (see Discussion), indicating that the ${ }^{40} \mathrm{Ar} /{ }^{39} \mathrm{Ar}$ ages approximate to intrusion ages and are not just a spread of cooling ages. In case of the more rapidly cooled Pine Island Bay trachyandesitic and granitoid dykes (LI-1, LI-2, LI-3), the plagioclase and $\mathrm{K}$-feldspar ${ }^{40} \mathrm{Ar} /{ }^{39} \mathrm{Ar}$ ages closely reflect the time of cooling and emplacement.

\section{Geochemistry}

Major and trace element data of all studied samples (except DR193-1) are given in Table IV. The samples from Backer Islands and Bear Peninsula are highly fractionated with $\mathrm{SiO}_{2}=71-75$ wt $\%$ and $\mathrm{Fe}_{2} \mathrm{O}_{3}=2-3$ wt $\%$, whereas the Wright Island samples show more intermediate compositions with $\mathrm{SiO}_{2}=56-64$ wt \% and $\mathrm{Fe}_{2} \mathrm{O}_{3}=5-8$ wt \%. The granitic Edwards Island dykes show evolved compositions with $\mathrm{SiO}_{2}=68.7 \mathrm{wt} \%$ and $68.6 \mathrm{wt} \%$, the trachyandesitic dyke has $\mathrm{SiO}_{2}=59.6 \mathrm{wt} \%$ and $\mathrm{MgO}=2.6 \mathrm{wt} \%$. All samples are metaluminous.

All analysed samples display multi-element patterns similar to I-type subduction-related rocks with the characteristic depletion in $\mathrm{Nb}$ and $\mathrm{Ta}$ and enrichment in fluid-mobile elements $\mathrm{Rb}, \mathrm{Ba}, \mathrm{U}, \mathrm{Pb}, \mathrm{Sr}$ and $\mathrm{K}$ (Fig. 6a).

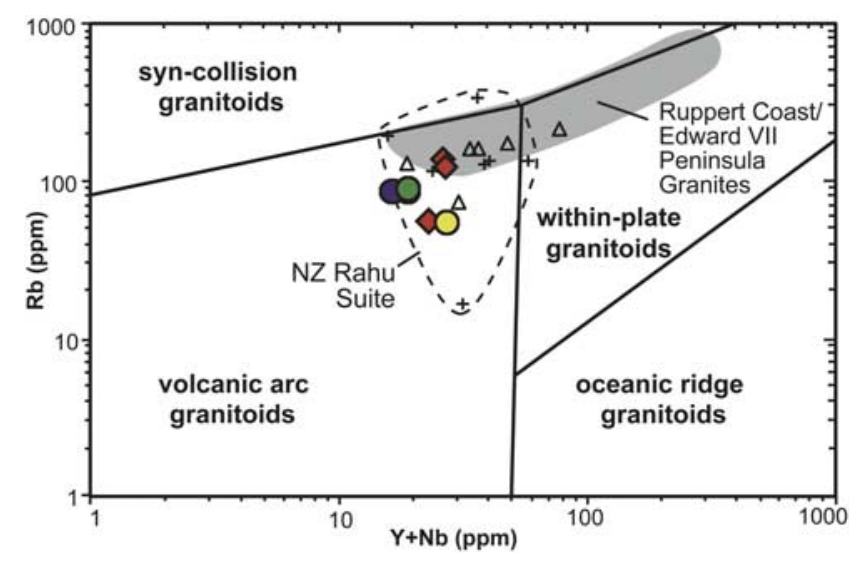

Fig. 8. $\mathrm{Y}+\mathrm{Nb}$ vs $\mathrm{Rb}$ tectonic discrimination diagram for granitoids after Pearce et al. (1984). The basement samples yielded on RV Polarstern ANT XXIII/4 cruise fall into the field for volcanic arc granitoids, consistent with a subduction setting for these rocks. Field for granites from Edward VII Peninsula and Ruppert Coast is based on published data from Weaver et al. 1992 and Pankhurst et al. 1998. Symbols as in Fig. 7.

The high concentrations in incompatible elements and the pronounced depletion in Ti reflect the evolved nature of the rocks. Negative anomalies of $\mathrm{Nb}, \mathrm{Ta}$, and in part in Ti may be caused by residual rutile during melting. The decrease in $\mathrm{Fe}_{2} \mathrm{O}_{3}$ and $\mathrm{TiO}_{2}$ with increasing $\mathrm{SiO}_{2}$ in the samples, however, also indicates fractionation of $\mathrm{Fe}-\mathrm{Ti}$ oxides. The negative $\mathrm{P}$ anomaly indicates fractionation of apatite. Their rare earth element patterns (Fig. 6b) reveal enrichment in light rare earth element (LREE) and relatively flat heavy rare earth element (HREE) patterns. The slight concave shape in the HREE patterns with relative depletion in Dy, $\mathrm{Ho}, \mathrm{Er}, \mathrm{Tm}$ relative to $\mathrm{Yb}, \mathrm{Lu}, \mathrm{Tb}$ and lighter REEs could reflect amphibole and/or apatite fractionation. A distinct negative Eu anomaly, as is commonly observed for evolved plutonic rocks from Marie Byrd Land and Ellsworth Land (e.g. Weaver et al. 1992) reflecting plagioclase fractionation, does not appear in the multi-element patterns of the MBL samples analysed in this study. A lack of a significant negative Eu anomaly in arc rocks is considered to be a characteristic feature of adakites (Defant \& Drummond 1990). Several further geochemical features of most of our samples may point to a weakly adakitic composition as, for example, high $\mathrm{SiO}_{2}(\geq 56 \mathrm{wt} \%)$ and $\mathrm{Al}_{2} \mathrm{O}_{3}$ ( $\geq 15 \mathrm{wt} \%$ ), low $<3 \% \mathrm{MgO}$ (Fig. 6), low $\mathrm{Nb}$ and Ta (Fig. 6a), and low HREE (e.g. Y and Yb, Figs 6 \& 7). We note, however, that most of these features could also be caused by plagioclase accumulation which is common in arc magmas.

Our whole rock geochemical data are the first such published analyses from Pine Island Bay and add to the Walgreen Coast and Thurston Island datasets of Pankhurst et al. $(1993,1998)$. 


\section{Discussion}

\section{Petrogenesis}

The range of rock types, along with major and trace element contents and ratios, support an origin for our analysed Pine Island Bay granitoids in a subduction-related setting (Fig. 8).

Except for the granite from Bear Peninsula, all of our samples show slightly elevated high $\mathrm{Sr} / \mathrm{Y}$ ratios (Fig. 7). In this regard they are similar to the moderate $\mathrm{Sr} / \mathrm{Y}$ 105-120 Ma Rahu Suite granites of New Zealand and also to sodic Cretaceous granites from the Antarctic Peninsula Batholith (Wareham et al. 1997). It is noteworthy that the entire MBL to Antarctic Peninsula part of the Cretaceous Gondwana margin lacks true adakitic and/or high $\mathrm{Sr} / \mathrm{Y}$ suites such as those that dominate Zealandia's Median Batholith in the time interval 105-130 Ma (Tulloch \& Kimbrough 2003).

The moderately enriched $\mathrm{Sr}-\mathrm{Nd}-\mathrm{Pb}$ isotopic composition of the $97 \mathrm{Ma}$ trachyandesite dyke sample PS69/LI-1 from Edwards Island (Table II) could either reflect derivation from a metasomatized mantle wedge source (possibly by melts from subducted marine sediments), or contamination of mantle derived melts by continental crust during ascent and prolonged crustal residence. In either case no evidence is found for the presence of a high $\mu\left(\mu={ }^{238} \mathrm{U} /{ }^{204} \mathrm{~Pb}\right)$ (HIMU) component in the source of the melt, as reported for Late Cretaceous mafic dykes in MBL by Storey et al. (1999).

\section{Age-composition patterns}

Our combined age and geochemical data indicate that Mesozoic continental arc magmatism occurred at least from c. $150 \mathrm{Ma}$ until $95 \mathrm{Ma}$ along the Walgreen Coast and in the Pine Island Bay area, consistent with previously published

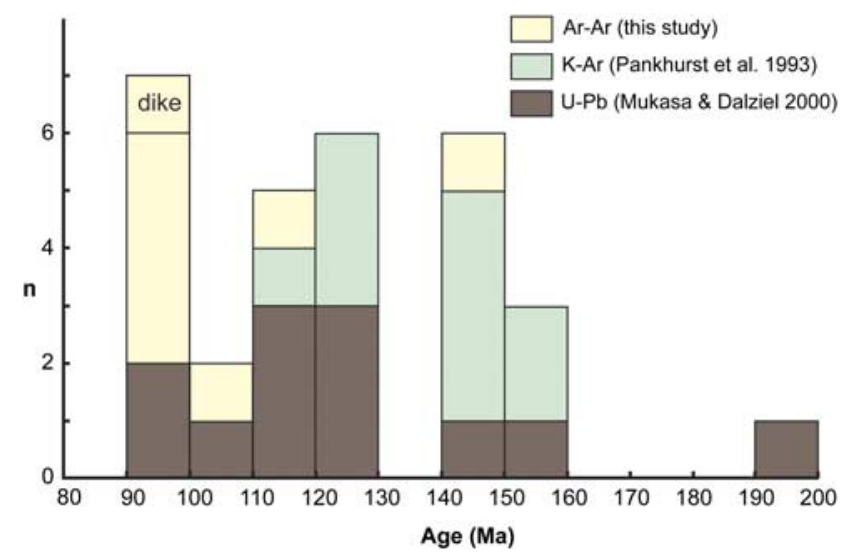

Fig. 9. Histogram comparing ages of Jurassic and Cretaceous Itype plutons in the Thurston Island-Pine Island Bay area. The youngest dated Mesozoic rock in the Pine Island Bay area (Fig. 2) is $94 \mathrm{Ma}$ (U-Pb zircon by Mukasa \& Dalziel 2000).

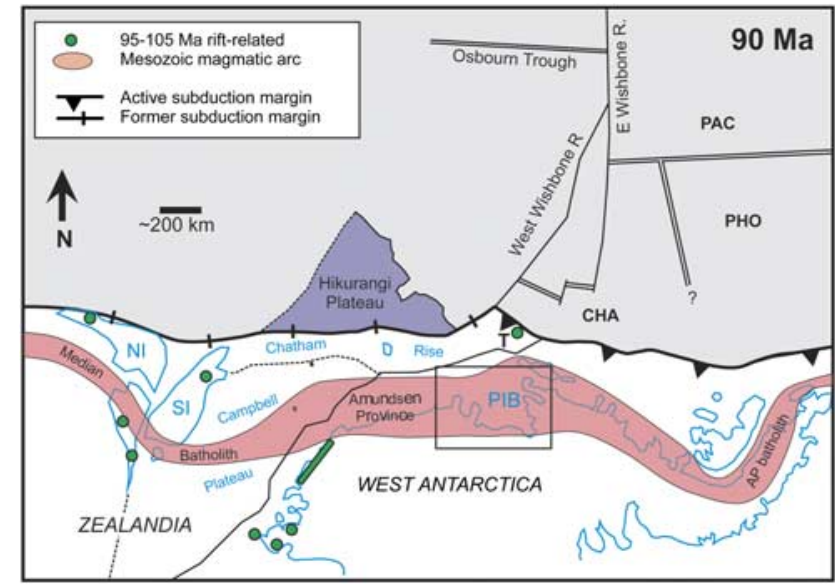

Fig. 10. Reconstruction of Zealandia and West Antarctica at $90 \mathrm{Ma}$, combining features from Eagles et al. (2004), and Mortimer et al. (2006). Note the wide zone of the magmatic arc in eastern Marie Byrd Land (MBL), possibly due to crustal extension after the Hikurangi Plateau-Chatham Rise collision and cessation of the subduction. The rectangle indicates the map area of Fig. $2(\mathrm{NI}=$ North Island of New Zealand, $\mathrm{SI}=$ South Island, $\mathrm{T}=$ Takahe Seamount, $\mathrm{PIB}=$ Pine Island Bay, $\mathrm{PAC}=$ Pacific Plate, $\mathrm{PHO}=$ Phoenix Plate, $\mathrm{CHA}=$ Charcot Plate).

$\mathrm{U}-\mathrm{Pb}$ and $\mathrm{K}-\mathrm{Ar}$ ages of I-type granitoids (Fig. 9, Mukasa \& Dalziel 2000). Notably, there seems to be a peak in magmatic activity between $c .100$ and $95 \mathrm{Ma}$, indicated by the closure temperatures of biotites from granitoids on Wright Island (98 Ma), U-Pb ages of granitoids from "McKenzie islands" (96 Ma) and Lindsey Island (94 Ma) (Mukasa \& Dalziel 2000), and the rapidly cooled dykes on Edwards Islands (95 and $97 \mathrm{Ma}$, respectively). Interestingly, this peak is within the age range of the Lassiter Coast Intrusive Suite in the southern Antarctic Peninsula (Flowerdew et al. 2005). We cannot exclude, however, the possibility that this peak reflects a sampling and/or cooling bias of this poorly mapped and lightly sampled area.

The persistence of I-type magmatism to $c$. $95 \mathrm{Ma}$ differs significantly from the seemingly abrupt change from I-type to A-type magmatism at 107-101 Ma along the Ruppert Coast of western MBL (Storey et al. 1999, Mukasa \& Dalziel 2000). It also differs from the situation in Zealandia where three pulses of I/A-type volcanism occurred at c. 101, c. 97 and c. 85 Ma with A-type character increasing with time (Tulloch et al. 2009). Tulloch et al. (2009) interpreted the onset of the earliest A-type magmatism at $101 \mathrm{Ma}$ to indicate the initial absence of a slab beneath Zealandia, and relate the decreasing degree of I-type geochemical characteristics in the younger suites to decreasing crustal contamination due to progressive crustal thinning. While no Cretaceous A-type igneous rocks have thus far been reported from sites east of Ruppert 
Coast, we note that the $97 \mathrm{Ma}$ Takahe A-type granite reconstructs to a position close to the western tip of Thurston Island (Fig. 10) (Mortimer et al. 2006). In the Antarctic Peninsula Batholith, Leat et al. (1995) noted that the most intense period of intermediate composition I- and IS-type magmatism was $142-97 \mathrm{Ma}$. They alluded to the existence of some $<97 \mathrm{Ma}$ alkaline igneous complexes but, unlike for Zealandia (Tulloch et al. 2009), these have not been interpreted as having any major regional tectonic significance for Gondwana margin tectonics.

\section{Cretaceous geodynamics}

The subduction-related I-type granitoids of Pine Island Bay are c. $500 \mathrm{~km}$ south of the present-day continent-ocean margin. No arc-trench gaps of this size exist today (Jarrard 1986). Between 100-200 km of this distance can be accounted for by post-subduction stretching of West Antarctica crust (Eagles et al. 2004). Arc-trench gaps of c. $300 \mathrm{~km}$ are observed in many modern day continental arcs (Jarrard 1986), and flat-slab subduction models have been proposed for the early Cretaceous Gondwana margin (Tulloch \& Kimbrough 2003).

Metamorphic core complexes and A-type granites developed in Zealandia and western MBL in the interval 100-85 Ma (Siddoway et al. 2004, Tulloch et al. 2009 and references therein). According to Eagles et al. (2004), a first phase of extension in the Zealandia/MBL region can be related to the establishment of a proto-Pacific-Antarctic plate boundary in the Bounty Trough and Great South Basin east and south-east of New Zealand South Island, resulting in considerable thinning of the continental lithosphere (Grobys et al. 2009 and references therein). This rift-phase led to the separation of the Chatham Rise from eastern MBL just after $90 \mathrm{Ma}$ (Eagles et al. 2004). At c. $84 \mathrm{Ma}$ the locus of rifting shifted to the boundary between the south-east margin of Campbell Plateau and the MBL margin, followed by sea floor spreading along the Pacific-Antarctic Ridge and the ultimate separation of Zealandia from Antarctica (Eagles et al. 2004). Evidence for crustal extension on the eastern MBL side can be found on the broad continental shelf of the Amundsen Sea embayment where geophysical data reveal a $22-24 \mathrm{~km}$ thin crust, and dominant magnetic lineaments are interpreted as rift-related mafic intrusions, parallel to the PacificAntarctic spreading axis (Gohl et al. 2007, Gohl in press). It is possible that continental rifting, which is associated with the West Antarctic Rift System, not only played a role in Ellsworth Land and its continental margin (Müller et al. 2007) but also affected the eastern MBL and Amundsen Sea embayment region (Jordan et al. 2010, Gohl in press).

The role of the Hikurangi Plateau in all this remains uncertain. The time of collision of the plateau with the Gondwana margin cannot be independently established but can only be inferred to be in the range of $105-65 \mathrm{Ma}$ from continental geology (Mortimer et al. 2006). This leads to circular arguments about cause and effect. The presence of alkalic HIMU-type volcanism on the Hikurangi Plateau and on the South Island of New Zealand beginning between 100 and 95 m.y. ago, however, suggests that the Hikurangi Plateau had already collided or was close to Zealandia by this time (Hoernle et al. 2010). Many aspects of the geology of the Gondwana margin (cessation of subduction, inception of rifting, slab windows) can equally be explained by subduction of a spreading ridge (Bradshaw 1989, Tulloch et al. 2009).

The present-day continental margin of the Amundsen Sea embayment and off the Walgreen Coast is not the old Gondwana subduction zone, but a Cretaceous rift margin, facing the currently active Pacific-Antarctic Ridge (Eagles et al. 2004, Gohl et al. 2007, Gohl in press). The extrapolation of oceanic crustal age from observed spreading anomaly $34 \mathrm{y}$ $(83 \mathrm{Ma})$ in the south-eastern Amundsen Sea towards the continent-ocean boundary of easternmost MBL results in an oldest estimated oceanic age of $c$. $90 \mathrm{Ma}$ (Eagles et al. 2004). This means that the eastern MBL region experienced a short rift phase of $<5-7$ m.y., before the subduction arc of the hinterland was converted to a Late Cretaceous passive margin.

\section{Acknowledgements}

We are grateful to Captain Pahl, the ship and helicopter crews, and shipboard scientific party for their excellent support during RV Polarstern cruise ANT-XXIII/4. S. Hauff and J. Sticklus are thanked for technical assistance, and W. Borchert for creating Figs 1 \& 2. Robert D. Larter kindly provided the dredge sample DR193.1. Discussions with Maxim Portnyagin, Jan Grobys, Graeme Eagles, Andreas Veit, and Christian Timm helped significantly to develop this paper. Comments on earlier versions of the manuscript by Phil Leat, Christine Siddoway, Alan Vaughan and an anonymous reviewer are appreciated. The German Research Foundation (DFG, grants HO1833/15-1 to -3 to $\mathrm{KH}$ and $\mathrm{FH}$ ) and the New Zealand Ministry of Science and Innovation funded this research.

\section{Supplemental material}

A supplemental table will be found at http://dx.doi.org/ $10.1017 /$ S0954102012000259.

\section{References}

BAKsI, A.K. 2007. A quantitative tool for detecting alteration in undisturbed rocks and minerals - I: water, chemical weathering, and atmospheric argon. Geological Society of America Special Paper, 430, 285-303.

Bradshaw, J.D. 1989. Cretaceous geotectonic pattern in the New Zealand region. Tectonics, 8, 803-820.

Carignan, J., Hild, P., Mevelle, G., Morel, J. \& Yeghicheyan, D. 2001. Routine analyses of trace elements in geological samples using flow, injection and low pressure online liquid chromatography coupled to ICP-MS: a study of reference materials BR, DR-N, UB-N, AN-G and GH. Geostandards Newsletter, 25, 187-198. 
Cassata, W.S., Renne, P.R. \& Shuster, D.L. 2009. Argon diffusion in plagioclase and implications for thermochronometry: a case study from the Bushveld Complex, South Africa. Geochimica et Cosmochimica Acta, 73, 6600-6612.

Craddock, C., Bastien, T.W. \& Rutford, R.H. 1964. Geology of the Jones Mountains area. In AdIE, R.J., ed. Antarctic geology. Amsterdam: North Holland Publishing, 171-187.

Davy, B., Hoernle, K. \& Werner, R. 2008. Hikurangi Plateau: crustal structure, rifted formation, and Gondwana subduction history. Geochemistry Geophysics Geosystems, 9, 10.1029/2007GC001855.

Defant, M.J. \& Drummond, M.S. 1990. Derivation of some modern arc magmas by partial melting of young subducted lithosphere. Nature, 347, 662-665.

Eagles, G., Gohl, K. \& Larter, R.D. 2004. High-resolution animated tectonic reconstruction of the South Pacific and West Antarctic margin. Geochemistry, Geophysics, Geosystems, 5, 10.1029/2003GC000657.

Flowerdew, M.J., Millar, I.L., Vaughan, A.P.M. \& Pankhurst, R.J. 2005. Age and tectonic significance of the Lassiter Coast intrusive suite, eastern Ellsworth Land, Antarctic Peninsula. Antarctic Science, 17, 443-452.

GoHL, K. In press. Basement control on past ice sheet dynamics in the Amundsen Sea embayment, West Antarctica. Palaeogeography, Palaeoclimatology, Palaeoecology, 10.1016/j.palaeo.2011.02.022.

Gohl, K., Teterin, D., Eagles, G., Netzeband, G., Grobys, J., Parsiegla, N., Schlüter, P., Leinweber, V., Larter, R.D., Uenzelmann-Neben, G. \& UdinTsev, G.B. 2007. Geophysical survey reveals tectonic structures in the Amundsen Sea embayment, West Antarctica. In Cooper, A.K., RAYMond, C.R. et al., eds. Antarctica: a keystone in a changing world online proceedings of the 10th international symposium of Antarctic earth sciences, USGS Open-File Report 2007-1047, Short Research Paper, 047.

Grobys, J.W.D., Gohl, K. \& Uenzelmann-Neben, G. 2009. Extensional and magmatic nature of the Campbell Plateau and Great South Basin from deep crustal studies. Tectonophysics, 472, 213-225.

Hoernle, K., Hauff, F., van den Bogatrd, P., Werner, R., Mortimer, N., Geldmacher, J., Garbe-Schönberg, D. \& Davy, B. 2010. Age and geochemistry of volcanic rocks from the Hikurangi and Manihiki oceanic plateaus. Geochimica et Cosmochimica Acta, 74, 7196-7219.

Hofmann, A.W. 1988. Chemical differentiation of the earth: the relationship between mantle, continental crust, and oceanic crust. Earth Planetary Science Letters, 90, 297-314.

JARRARD, R.D. 1986. Relations among subduction parameters. Reviews of Geophysics, 24, 217-284.

Jordan, T.A., Ferraccioli, F., Vaughan, D.G., Holt, J.W., Corr, H., BLANKENShiP, D.D. \& DieHL, T.M. 2010. Aerogravity evidence for major crustal thinning under the Pine Island Glacier region (West Antarctica). Geological Society of America Bulletin, 122, 714-726.

LANPhere, M.A. \& Dalrymple, G.B. 2000. First-principles calibration of ${ }^{38} \mathrm{Ar}$ tracers: implications for the ages of ${ }^{40} \mathrm{Ar} /{ }^{39} \mathrm{Ar}$ fluence monitors. United States Geological Survey Professional Paper, 1621, 1-10.

Leat, P.T., Scarrow, J.H. \& Millar, I.L. 1995. On the Antarctic Peninsula batholith. Geological Magazine, 132, 399-412.

Leat, P.T., Storey, B.C. \& Pankhurst, R.J. 1993. Geochemistry of Palaeozoic-Mesozoic Pacific rim orogenic magmatism, Thurston Island area, West Antarctica. Antarctic Science, 5, 281-296.

LUYENDYK, B.P. 1995. Hypothesis for Cretaceous rifting of East Gondwana caused by subducted slap capture. Geology, 23, 373-376.

Maslany, M. \& StoRey, B.C. 1990. Regional aeromagnetic anomalies in Ellsworth Land: crustal structure and Mesozoic microplate boundaries within West Antarctica. Tectonics, 9, 1515-1532.

McDonough, W.F. \& Sun, S.-S. 1995. The composition of the Earth. Chemical Geology, 120, 223-253.
McDougall, I. \& Harrison, T.M. 1999. Geochronology and thermochronology by the ${ }^{40} \mathrm{Ar}{ }^{39} \mathrm{Ar}$ method, 2nd ed. Oxford: Oxford University Press, 269 pp.

Mortimer, N., Hoernle, K., Hauff, F., Palin, J.M., Dunlop, W.J., Werner, R. \& FAURE, K. 2006. New constraints on the age and evolution of the Wishbone Ridge, southwest Pacific Cretaceous microplates, and Zealandia-West Antarctica breakup. Geology, 34, 185-188.

Mukasa, S.B. \& Dalziel, I.W.D. 2000. Marie Byrd Land, West Antarctica: evolution of the Gondwana's Pacific margin constrained by zircon U-Pb geochronology and feldspar common- $\mathrm{Pb}$ isotopic compositions. Geological Society of America Bulletin, 112, 611-627.

Müller, R.D., Gohl, K., Cande, S.C., Goncharov, A. \& Golynsky, A.V. 2007. Eocene to Miocene geometry of the West Antarctic Rift System. Australian Journal of Earth Sciences, 54, 1033-1045.

Pankhurst, R.J., Millar, I.L., Grunow, A.M. \& Storey, B.C. 1993. The pre-Cenozoic magmatic history of the Thurston Island crustal block, West Antarctica. Journal of Geophysical Research, 98, 11 835-11 849.

Pankhurst, R.J., Weaver, S.D., Bradshaw, J.D., Storey, B.C. \& Ireland, T.R. 1998. Geochronology and geochemistry of pre-Jurassic superterranes in Marie Byrd Land, Antarctica. Journal of Geophysical Research, 103, 2529-2547.

Pearce, J.A., Harris, N.B.W. \& Tindle, A. 1984. Trace element discrimination diagrams for the tectonic interpretation of granitic rocks. Journal of Petrology, 25, 956-983.

Richards, J.P. \& KerRick, R. 2007. Adakite-like rocks: their diverse origins and questionable role in metallogenesis. Economic Geology, Special Paper, 102, 537-576.

Siddoway, C.S., Baldwin, S., Fitzgerald, P.G., Fanning, C.M. \& LUYEDNDYK, B.P. 2004. Ross Sea mylonites and the timing of intracontinental extension within the West Antarctic Rift System. Geology, 32, 57-60.

Sмith, W.H.F. \& SANDwELl, D.T. 1997. Global seafloor topography from satellite altimetry and ship depth soundings. Science, 277, 1956-1962.

Storey, B.C., Leat, P.T., Weaver, S.D., Pankhurst, R.J., Bradshaw, J.D. \& Kelley, S. 1999. Mantle plumes and Antarctica-New Zealand rifting: evidence from mid-Cretaceous mafic dykes. Journal of the Geological Society, 156, 659-671.

Tulloch, A.J. \& Kimbrough, D.L. 2003. Paired plutonic belts in convergent margins and the development of high $\mathrm{Sr} / \mathrm{Y}$ magmatism: peninsular ranges batholith of Baja California and median batholith of New Zealand. Geological Society of America Special Paper, 374, 275-295.

Tulloch, A.J., Ramezani, J., Mortimer, N., Mortensen, J., van den Bogatrd, P. \& MaAs, R. 2009. Cretaceous felsic volcanism in New Zealand and Lord Howe Rise (Zealandia) as a precursor to final Gondwana break-up. In RING, U. \& Wernicke, B., eds. Extending a continent: architecture, rheology and heat budget. Geological Society of London Special Publication, No. 321, 89-118.

VAughan, A.P.M. \& STOREY, B.C. 2000. The eastern Palmer Land shear zone: a new terrane accretion model for the Mesozoic development of the Antarctic Peninsula. Journal of the Geological Society, 157, 1243-1256.

Wareham, C.D., Millar, I.L. \& Vaughan, A.P.M. 1997. The generation of sodic granite magmas, western Palmer Land, Antarctic Peninsula. Contributions to Mineralogy and Petrology, 128, 81-96.

Weaver, S.D., Adams, C.J., Pankhurst, R.J. \& Gibson, I.L. 1992. Granites of the Edward VII Peninsula, Marie Byrd Land: anorogenic magmatism related to Antarctic - New Zealand rifting. Transactions of the Royal Society of Edinburgh, Earth Sciences, 83, 281-290.

Weaver, S.D., Storey, B.C., Pankhurst, R.J., Mukasa, S.B., DiVenere, V.J. \& BRadshaw, J.D. 1994. Antarctica-New Zealand rifting and Marie Byrd Land lithospheric magmatism linked to ridge subduction and mantle plume activity. Geology, 22, 811-814. 